\title{
A Recombinant Sal k 1 Isoform as an Alternative to the Polymorphic Allergen from Salsola kali Pollen for Allergy Diagnosis
}

\author{
Salvador Mas ${ }^{a}$ Patrice Boissy ${ }^{b}$ Rafael I. Monsalve ${ }^{b} \quad$ Javier Cuesta-Herranz ${ }^{c}$ \\ Araceli Díaz-Perales ${ }^{d} \quad$ Javier Fernández ${ }^{\mathrm{e}} \quad$ Carlos Colás $^{f} \quad$ Rosalía Rodríguez $^{\mathrm{a}}$ \\ Rodrigo Barderas ${ }^{a}$ Mayte Villalba ${ }^{a}$ \\ a Departamento de Bioquímica y Biología Molecular I, Universidad Complutense de Madrid, b'ALK-Abelló S.A., \\ and ${ }^{\mathrm{C} H o s p i t a l}$ Fundación Jiménez Díaz, Madrid, ${ }^{\mathrm{d} C e n t r o ~ d e ~ B i o t e c n o l o g i ́ a ~ y ~ G e n o ́ m i c a ~ d e ~ P l a n t a s, ~ C a m p u s ~ d e ~}$ \\ Montegancedo, Pozuelo de Alarcón, e Departamento Medicina Clínica, Universidad Miguel Hernández de Elche, \\ Alicante, and ${ }^{\mathrm{f}}$ Hospital Clínico Universitario 'Lozano Blesa', Zaragoza, Spain
}

\section{Key Words}

Sal k 1 - Salsola kali pollinosis - Amaranthaceae .

Recombinant allergen · Cross-reactivity · Pectin

methylesterase

\begin{abstract}
Background: The incidence of Amaranthaceae pollen allergy has increased due to the desertification occurring in many countries. In some regions of Spain, Salsola kali is the main cause of pollinosis, at almost the same level as olive and grass pollen. Sal k 1 - the sensitization marker of S. kali pollinosis - is used in clinical diagnosis, but is purified at a low yield from pollen. We aimed to produce a recombinant ( $r$ )Sal $\mathrm{k} 1$ able to span the structural and immunological properties of the natural isoforms from pollen, and validate its potential use for diagnosis. Methods: Specific cDNA was amplified by $P C R$, cloned into the $\mathrm{pET} 41 \mathrm{~b}$ vector and used to transform BL21 (DE3) Escherichia coli cells. Immunoblotting, ELISA, basophil activation and skin-prick tests were used to validate the recombinant protein against Sal $\mathrm{k} 1$ isolated from pollen. Sera and blood cells from S. kali pollen-sensitized patients and specific monoclonal and polyclonal antisera were used.
\end{abstract}

Results: rSal $\mathrm{k} 1$ was produced in bacteria with a yield of 7.5 $\mathrm{mg} / \mathrm{l}$ of cell culture. The protein was purified to homogeneity and structural and immunologically validated against the natural form. rSal k 1 exhibited a higher lgE cross-reactivity with plant-derived food extracts such as peanut, almond or tomato than with pollen sources such as Platanus acerifolia and Oleaceae members. Conclusions: rSal k 1 expressed in bacteria retains intact structural and immunological properties in comparison to the pollen-derived allergen. It spans the immunological properties of most of the isoforms found in pollen, and it might substitute natural Sal k 1 in clinical diagnosis.

(c) 2015 S. Karger AG, Basel

\section{Introduction}

It is a wide repertoire of plant families that produces relevant allergenic pollens [1,2]. Pollens from the Amaranthaceae family are gaining relevance as allergenic inducers in countries where climate change is causing an extensive desertification, because these resistant weeds are able to rapidly colonize these areas [3]. The most rel-

\section{KARGER 125}

(c) 2015 S. Karger AG, Base

$1018-2438 / 15 / 1672-0083 \$ 39.50 / 0$

E-Mail karger@karger.com

www.karger.com/iaa
Correspondence to: Dr. Mayte Villalba and Dr. Rodrigo Barderas

Departamento de Bioquímica y Biología Molecular

Facultad de Ciencias Químicas, Universidad Complutense ES-28040 Madrid (Spain)

E-Mail mayte@bbml.ucm.es and rbarderas@quim.ucm.es 
evant members of this family in the Mediterranean area are Salsola kali and Chenopodium album $[4,5]$.

S. kali is the species of the Amaranthaceae family best characterized from an allergenic point of view, with the first sensitization cases to this pollen reported in 1933 in Arizona, USA [6]. Nowadays, multiple sensitizations to $S$. kali pollen have been described, since this weed can be found extensively worldwide. S. kali can be found from the northeast to the west of the USA, from the Baltic to the Mediterranean coast in Europe and in North Africa and the Arab states [6-8]. In the southeastern and central areas of Spain, S. kali pollen has become one of the first causes of seasonal allergy at almost the same level as olive and grass pollinosis $[4,5,9]$.

Despite the significant IgE cross-reactivity observed between these members of the Amaranthaceae family [10], about $10-30 \%$ of allergic patients are sensitized mainly to $S$. kali [11]. Several allergens from C. album (Che a 1 [12], Che a 2 and Che a 3 [13]) and S. kali [Sal k 1 [11], Sal k 2 (accession No. Q8L5K9), Sal k 3 [14], Sal k $4[15,16]$ and Sal k 5 [17]] pollens have been identified (for a review, see [18]). Sal $\mathrm{k} 1$ is the allergenic marker of S. kali pollen able to discriminate between sensitized and nonsensitized patients to this weed [11]. The average prevalence of Sal k 1, a pectin methylesterase (PME), in certain areas of Spain, is about $18 \%$ in pollen-sensitized patients and about $70 \%$ in S. kali pollen-sensitized patients, as revealed by the multicenter study, 'VEGETALIA' and 'EXPO' [19]. The same cohort of patients showed a prevalence of $2 \%$ to the major allergen of C. album (Che a 1) or S. kali (Sal k5) in all pollen-sensitized patients [19], thus confirming the role of the Ole e 1-like protein family as a sensitization marker of the Amaranthaceae sp.

In addition to Sal k 1, PMEs from olive (Olea europaea) pollen (Ole e 11), tomato (Lycopersicon esculentum) and kiwi fruit (Actinidia deliciosa) have also been reported as allergens [20-23]. Sal k 1 shares an amino acid sequence identity of 57,17 and $23 \%$ with olive pollen, tomato and kiwi PMEs, respectively. Despite this low identity observed between PMEs from pollens and plant-derived foods, these proteins possess a catalytic core highly conserved during evolution, containing A153, Q173, D174, D195 and R253 residues in Sal k 1. This region might enable PME crossreactivity processes from different sources since, on immunoblotting, a significant IgG recognition could be observed when comparing PMEs from olive pollen and other plantderived food sources such as avocado, pear or tomato [20].

Sal k 1 purified from pollen is already being used in commercial diagnostic protocols to determine the specific IgE levels of patients by ImmunoCAP (Thermo Fish- er Scientific). However, Sal $\mathrm{k} 1$ is purified from pollen at a very low yield (100 $\mu \mathrm{g}$ of homogeneous protein from $5 \mathrm{~g}$ of dried pollen [11]), and it contains a mixture of many different isoforms. As a different isoform composition is obtained from batch to batch, the availability of a wellcharacterized recombinant isoform equivalent to the natural allergenic isoforms present in $S$. kali pollen would be a useful tool to standardize diagnostic and immunotherapeutic protocols. In addition, other advantages of the availability of recombinant allergens are based on 2 pillars: (1) the consistency of the recombinant production, ensuring that the same results will be obtained in different batches of the product used for diagnosis and therapy and (2) an increase in specificity can be obtained since the glycosylation present in natural allergens can produce falsepositive results in a significant percentage of allergic patients. The recombinant Sal k 1 protein would circumvent the batch-to-batch variability and allergen concentration issues of the $S$. kali protein extracts used in diagnostic and immunotherapeutic protocols [24, 25].

In this context, the aim of this work consisted of the production of a recombinant isoform of Sal k 1 able to span the structural and immunological properties of the natural isoforms present in S. kali pollen, and then validate its use for the diagnosis of $S$. kali allergy. In addition, we found that the PME could be implicated in pollenpollen and plant-derived food-pollen cross-reactivity processes.

\section{Materials and Methods}

Protein Extracts and Natural Sal $k 1$ Purification

Pollen from several plant species was obtained from ALKAbelló S.A., Madrid, Spain. Pollen protein extracts were prepared by saline extraction as described previously [12]. Plant-derived food extracts from fruits and nuts were prepared as previously described [26]. Protein extract concentration was determined using the bicinchoninic acid assay (Pierce Chemical Co., Thermo Fisher Scientific, Rockford, Ill., USA).

Natural (n)Sal k 1 purified to homogeneity was obtained as previously reported [11].

\section{Cloning Strategy}

PCR amplification of the S. kali PME isoform Sal k 1.0103 was performed using the template previously cloned in the PCR2.1 vector (Invitrogen, Groningen, The Netherlands) [11]. Two specific oligonucleotides were designed: a sense primer with an NdeI restriction site (underlined), $5^{\prime}$-actcatATGCAGCCGATCCCCCCT $-3^{\prime}$, that corresponds to the MQPIPP amino acid sequence (the N-terminal end of the mature protein) and an antisense primer, $5^{\prime}$-ttactcgagCACTTTAGGTGGTGGTAG-3', with an XhoI restriction site (underlined) that corresponds to LPPPKV amino acids (C-terminal end of Sal k 1). The amplified PCR product was DOI: $10.1159 / 000434680$
Mas et al. 
then digested with $\mathrm{NdeI}$ and XhoI restriction enzymes and cloned into the pET41b plasmid (Invitrogen) in phase with a nucleotide sequence codifying for an $8 \times$ His tag, included in the expression vector at the C-terminus of the protein.

\section{Expression and Purification of Recombinant Sal $k 1$}

The construct pET41b/Sal k 1.0103 was used to transform Escherichia coli BL21 (DE3) cells according to [15]. BL21 (DE3) cultures were centrifuged at $6,000 \mathrm{~g}$ for $20 \mathrm{~min}$ and reconstituted in $20 \mathrm{mM}$ of sodium phosphate ( $\mathrm{pH} 8.0$ ) containing $0.5 \mathrm{M}$ sodium chloride, 20 $\mathrm{mM}$ imidazole and $1 \mathrm{~mm}$ phenylmethane-sulfonylfluoride. After bacterial lysis by 3 cycles of freezing in $\mathrm{N}_{2}$ and thawing at $42^{\circ} \mathrm{C}$, the soluble fraction containing recombinant $(\mathrm{r}) \mathrm{Sal} \mathrm{k} 1 \mathrm{was}$ clarified by centrifugation at $12,000 \mathrm{~g}$ for $20 \mathrm{~min}$, and subsequently loaded in an AKTA Purifier FPLC system with a His-Trap FF crude (both from GE Healthcare, Madrid, Spain). The elution of the protein was performed using an isocratic gradient of $0.5 \mathrm{M}$ of imidazole in reconstitution buffer according to Loughran and Walls [27].

\section{Sera and Antibodies}

Sera from 80 patients suffering from Amaranthaceae pollinosis were collected from 3 regions of Spain: Zaragoza, Murcia and Alicante (see www.karger.com/doi/10.1159/000434680 for online suppl. table S1). Written informed consent was obtained from all patients. The nonatopic controls were selected according to a nonallergic history and negative skin-prick tests to the usual panel of respiratory allergens.

Rabbit polyclonal antiserum against the natural PME from $S$. kali pollen was obtained by weekly injections of the protein (100 $\mu \mathrm{g}$ ) in complete Freund's adjuvant. Horseradish peroxidase (HRP)-labeled goat polyclonal antibody (pAb) against rabbit IgG was obtained from Bio-Rad (Richmond, Calif., USA). Mouse monoclonal antibody $(\mathrm{mAb})$ against human $\operatorname{IgE}$ and $2 \mathrm{mAbs}$, i.e.

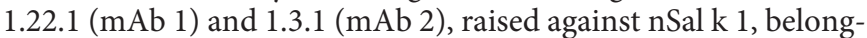
ing to different families, were obtained in collaboration with ALKAbelló. HRP-labeled goat pAb against mouse IgG was purchased from Pierce Chemical Co. HRP-labeled mouse pAb against the His tag was from Sigma-Aldrich (St. Louis, Mo., USA).

\section{MS Analysis and CD Spectroscopy}

MS of purified proteins (MALDI experiments) were performed on an Autoflex III MALDI-TOF-TOF instrument (Bruker Daltonics, Bremen, Germany) with a smartbeam laser in the Proteomics and Genomics Facility of the CIB-CSIC, a member of ProteoRedISCIII network.

The CD spectra recording and deconvolution of data was obtained in the far-UV, on a Jasco J-715 spectropolarimeter (Japan Spectroscopic Co., Tokyo, Japan) according to Mas et al. [15]. Theoretical percentages of secondary structure were obtained by means of the GOR method [28].

\section{Analytical Procedures}

SDS-PAGE was performed in $15 \%$ polyacrylamide gels. Proteins were stained with Coomassie blue R-250 (Sigma-Aldrich). Molecular mass determinations were done with protein molecular mass markers SM0431 (Fermentas, Thermo Fisher Scientific). The concentration of the purified proteins was calculated by measuring the absorbance at $280 \mathrm{~nm}$ in a DU-7 spectrometer (Beckman, Madrid, Spain) using the theoretical extinction coefficient $\left(\mathrm{E}^{0.1 \%}\right)$ of 1.1 of Sal k 1.0103 obtained using the ProtParam Software [29].

Recombinant Production of Sal k 1, a

Sensitization Marker of S. kali

\section{Immunological Characterization}

Immunoblotting procedures were developed as described previously [15] using individual human sera (diluted 1:10), anti-human IgE mAb (diluted 1:3,000) and HRP-labeled anti-mouse IgG antibody or a rabbit polyclonal antiserum raised against nSal $\mathrm{k} 1$ (diluted 1:50,000) followed by HRP-labeled anti-rabbit IgG pAb (1:3,000). Alternatively, an HRP-labeled mouse pAb against His tag $(1: 2,000)$ or $\mathrm{mAbs}$ raised against $\mathrm{nSal} \mathrm{k} 1$ (1:200) followed by an HRP-labeled anti-mouse IgG antibody $(1: 2,500)$ were used. For immunoblotting inhibition assays, an equivolumetric pool of sera $(\mathrm{n}=8$; diluted $1: 10)$ was alternatively preincubated with 0,1 or $5 \mu \mathrm{g}$ of rSal k 1 or, alternatively, nSal k 1 . Protein bands were quantified by densitometry using the Multi Gauge analysis software (Fujifilm, Barcelona, Spain) and referring the inhibition percentage to the control without inhibitor [17].

Indirect ELISA was performed as described [30] in 96-well plates coated with $100 \mathrm{ng}$ of recombinant protein, $20 \mu \mathrm{g}$ of pollen extract or $500 \mathrm{ng}$ of pineapple-stem bromelain [31] (Sigma-Aldrich). OD values $>0.1$ arbitrary units (mean $+3 \times \mathrm{SD}$ of the OD of the negative control) were considered positive. Inhibition assays were performed with an equivolumetric pool of human sera $(\mathrm{n}=8$; diluted $1: 10)$, the anti-nSal k 1 polyclonal antiserum (diluted $1: 50,000)$ or $\mathrm{mAbs}$ raised against nSal k 1 (1:10,000), previously adsorbed to different concentrations of inhibitors ranging from $1 \mathrm{ng}$ to $5 \mu \mathrm{g}$ for purified proteins and 20 or $200 \mu \mathrm{g}$ for the pollen and plant-derived food extracts. Binding of human IgE was detected by anti-human IgE mAb (diluted 1:5,000) followed by HRP-labeled anti-mouse IgG antibody (diluted 1:2,500). The binding of anti-Sal $\mathrm{k} 1$ polyclonal antiserum was detected with the HRP-labeled anti-rabbit IgG antibody $(1: 3,000)$ and binding of mouse mAbs with the HRP-labeled antibody $(1: 2,500)$. The inhibition percentage was calculated according to the formula: inhibition $(\%)=\left[1-\left(\mathrm{Abs}_{492 \mathrm{~nm}}\right.\right.$ with inhibitor/Abs $492 \mathrm{~nm}$ without inhibitor) $] \times 100[17]$.

\section{Basophil Activation Test}

This test was performed as previously described [32]. After blood-cell separation, $50 \mu \mathrm{l}$ of each patient's cell suspension was incubated with $50 \mu \mathrm{l}$ of indicated protein concentration. To evaluate background basal values without stimulation (negative control), we added $50 \mu$ of stimulation buffer (cRPMI), containing IL-3 $(2 \mathrm{ng} / \mathrm{ml})$ in the cell suspension. As a positive control, a monoclonal anti-IgE anti-receptor antibody was used at a final concentration of $1 \mu \mathrm{g} / \mathrm{ml}$. A positive response was concluded for values $\geq 15 \%$, and a stimulation index (antigen-specific response/basal level) $\geq 2$.

\section{Results}

\section{Cloning, Recombinant Production and Purification of rSalk 1}

We previously reported the polymorphic character of Sal $\mathrm{k} 1$ allergen and the sequencing of 3 different isoforms: Sal k 1.0101 (AY590141), Sal k 1.0102 (AY776249) and Sal k 1.0103 (AY776248), which showed 94-99\% identity in their amino acid sequences [11]. 


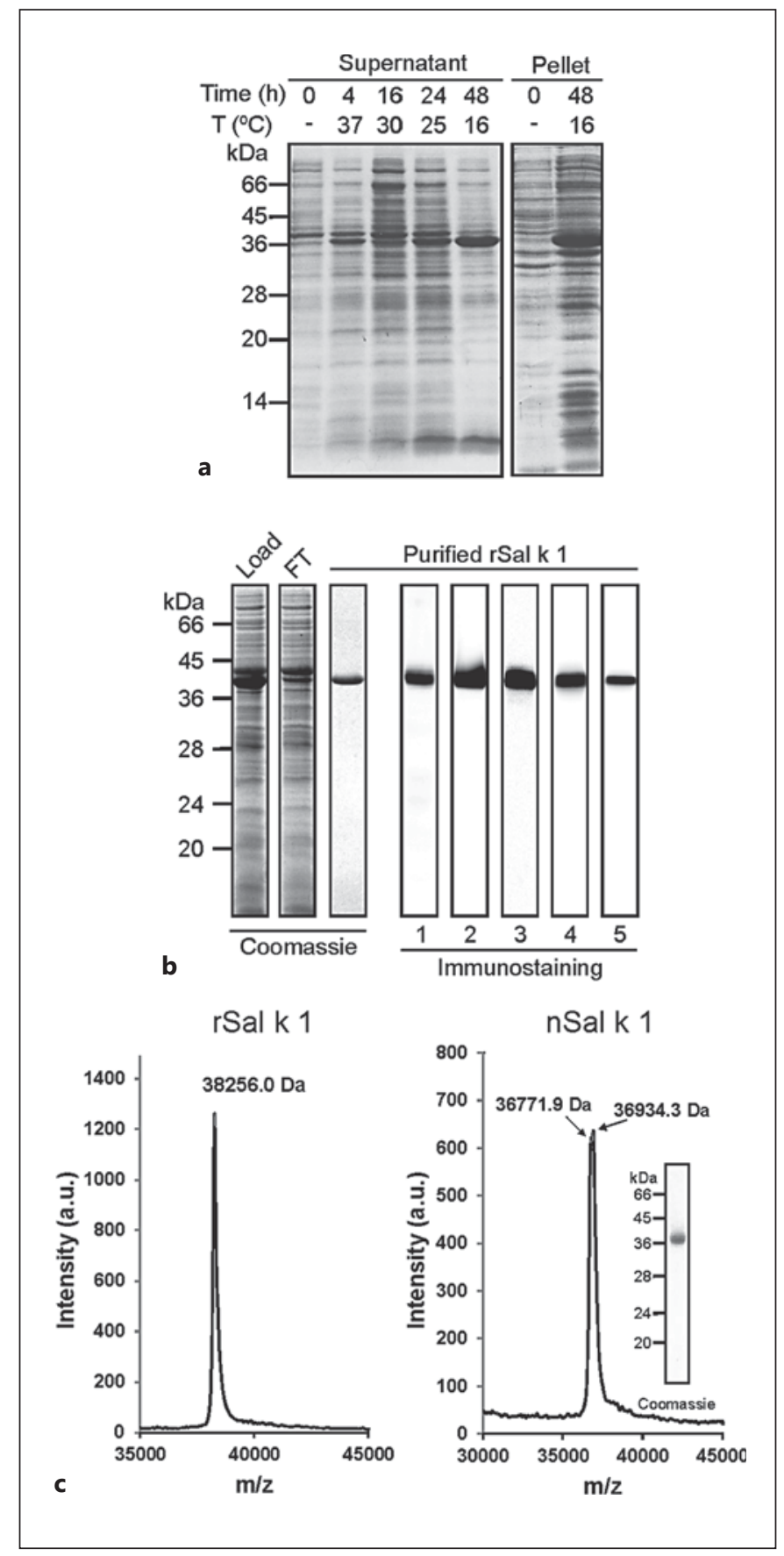

Fig. 1. Recombinant expression and purification of Sal k 1. a SDSPAGE analysis of the time-course of the recombinant expression of Sal k 1 in E. coli BL21 (DE3) cells at indicated temperatures and times of induction with IPTG. b SDS-PAGE of the purification process of rSal $\mathrm{k} 1$ and immunostaining of nitrocellulose-blotted proteins with: an equivolumetric pool of allergic patients' sera (1), $\mathrm{mAb} 1$ (2), mAb 2 (3), the polyclonal antiserum raised against $\mathrm{nSal}$ $\mathrm{k} 1$ (4) and the pAb against His tag (5). Molecular mass markers are shown. FT = Flow-through. $\mathbf{c}$ Left: MS analysis of rSal k 1 in arbitrary units (a.u.). Right: MS analysis of $\mathrm{nSal} k 1$ purified from pollen. Inset Coomassie blue staining of nSal k 1 .

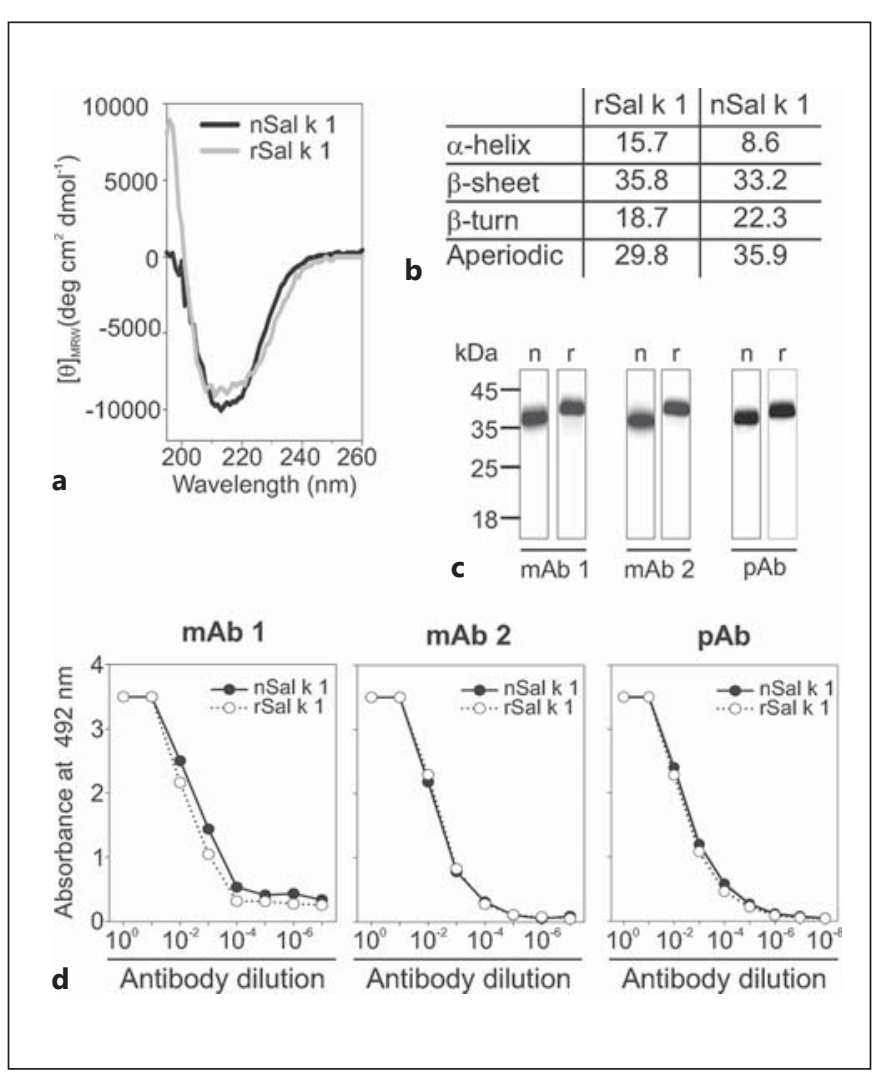

Fig. 2. Structural and antigenic properties of $\mathrm{rSal} \mathrm{k} 1$ in comparison to nSal k 1. a Circular dichroism spectra of nSal k 1 and rSal k 1 at a concentration of $200 \mathrm{ng} / \mu \mathrm{l}$. b Percentages of secondary structure of both proteins were obtained by deconvolution with the GOR method. c SDS-PAGE and immunoblot of nitrocellulose-blotted $200 \mathrm{ng}$ of $\mathrm{nSal} \mathrm{k} 1$ and $\mathrm{rSal} \mathrm{k} 1$ with $\mathrm{mAb} 1, \mathrm{mAb} 2$ and the pAb raised against $\mathrm{nSal} \mathrm{k}$. Molecular mass markers are shown. $\mathbf{d} \mathrm{Ti}$ tration of $\mathrm{mAb} 1, \mathrm{mAb} 2$ and $\mathrm{pAb}$. ELISA plates were coated with $100 \mathrm{ng} /$ well of rSal k 1 or nSal k 1 .

Here, we aimed to express, purify and characterize a recombinant isoform of Sal k 1, which might be a replacement for $\mathrm{nSal} \mathrm{k} 1$ in diagnostic protocols. To this end, we amplified the cDNA-encoding mature Sal k 1.0103 by PCR, and cloned it into the pCR2.1 vector. The cDNA was then subcloned into the expression vector pET41b, and the construct was subsequently used to transform BL21 (DE3) cells to produce Sal k 1, as a protein tagged at the $\mathrm{C}$-terminus with an $8 \times$ His sequence.

Different temperatures and IPTG-induction times were surveyed, and the supernatants and pellets analyzed by Coomassie blue staining to determine the optimal conditions to produce $\mathrm{rSal} \mathrm{k} 1$. The highest yield of soluble recombinant protein was observed at $16^{\circ} \mathrm{C}$ and $48 \mathrm{~h}$ of induction with $1 \mathrm{mM} \mathrm{IPTG} \mathrm{(fig.} \mathrm{1a).}$ DOI: $10.1159 / 000434680$
Mas et al. 
After affinity chromatography, fractions containing the homogeneous recombinant protein were pooled, dialyzed and concentrated, and then used in subsequent experiments. rSal $\mathrm{k} 1$ was obtained with yields of approximately $7.5 \mathrm{mg} / \mathrm{l}$ of cell culture. The recombinant protein integrity and purity was verified by Coomassie blue staining after SDS-PAGE and mass spectrometry. rSal k 1 was also tested with (1) a pool of sera from allergic patients to S. kali, (2) 2 specific mAbs, mAb 1 and $\mathrm{mAb} 2$, (3) 1 polyclonal antiserum raised against $\mathrm{nSal} k 1$ and (4) a pAb directed against the His tag, after transference to the membranes to assess its immunological integrity and equivalence to $\mathrm{nSal} \mathrm{k} 1$ isolated from pollen (fig. $1 \mathrm{~b}$ ). Finally, we performed MS analysis of the purified recombinant protein (fig. 1c). The molecular mass of rSal k 1 was $38,256 \mathrm{Da}$, coincident with the theoretical molecular mass of Sal k 1.0103 plus the extra amino acids at the Cterminal end composed of Leu-Glu and the $8 \times$ His tag. Furthermore, we confirmed the absence of contaminants in rSal k 1. Finally, Coomassie blue staining and MS analysis confirmed the absence of contaminants of the natural protein isolated from pollen and that $\mathrm{nSal} \mathrm{k} 1$ is a highly polymorphic protein (fig. 1c).

Collectively, these experiments assessed the purity and integrity of the recombinant allergen produced in bacteria and isolated to homogeneity.

\section{Structural Characterization of $r$ Sal $k 1$}

To structurally and immunologically characterize rSal $\mathrm{k} 1$ in comparison to $\mathrm{nSal} \mathrm{k} 1$, we first performed $\mathrm{CD}$ analyses using rSal $\mathrm{k} 1$ and $\mathrm{nSal} \mathrm{k} 1$ at a concentration of 200 $\mu \mathrm{g} / \mathrm{ml}$ (fig. 2a). Similar CD spectra were obtained for both proteins. We observed a higher $\alpha$-helix content in $\mathrm{rSal} k \mathrm{k}$ ( 15.7 vs. $8.6 \%$ for $\mathrm{nSal} \mathrm{k} 1$ ) and minor differences in the $\beta$-sheet and $\beta$-turn structure content. However, we observed a higher aperiodic content for $\mathrm{nSal} \mathrm{k} 1$ than for $\mathrm{rSal}$ $\mathrm{k} 1$ (29.8 vs. $35.9 \%$ for $\mathrm{nSal} \mathrm{k} 1$ ), suggesting a subtle partial denaturation of $\mathrm{nSal} \mathrm{k} 1$, probably during the purification procedure of the natural allergen from pollen (fig. $2 b$ ).

\section{Immunological Characterization}

We analyzed the antigenic properties of both recombinant and natural Sal $\mathrm{k} 1$ by ELISA and Western blot (WB) using 2 different mouse mAbs and a polyclonal antiserum raised against $\mathrm{nSal} \mathrm{k} 1$. By WB, under denaturing conditions, we observed that the ability of both variants to bind IgG from the mAbs and the polyclonal antisera was equivalent (fig. 2c). ELISA titration of $\mathrm{mAb} 1, \mathrm{mAb}$ 2 and the polyclonal antisera with $\mathrm{rSal} \mathrm{k} 1$ and nSal k 1 showed that the IgG-binding ability of both proteins was

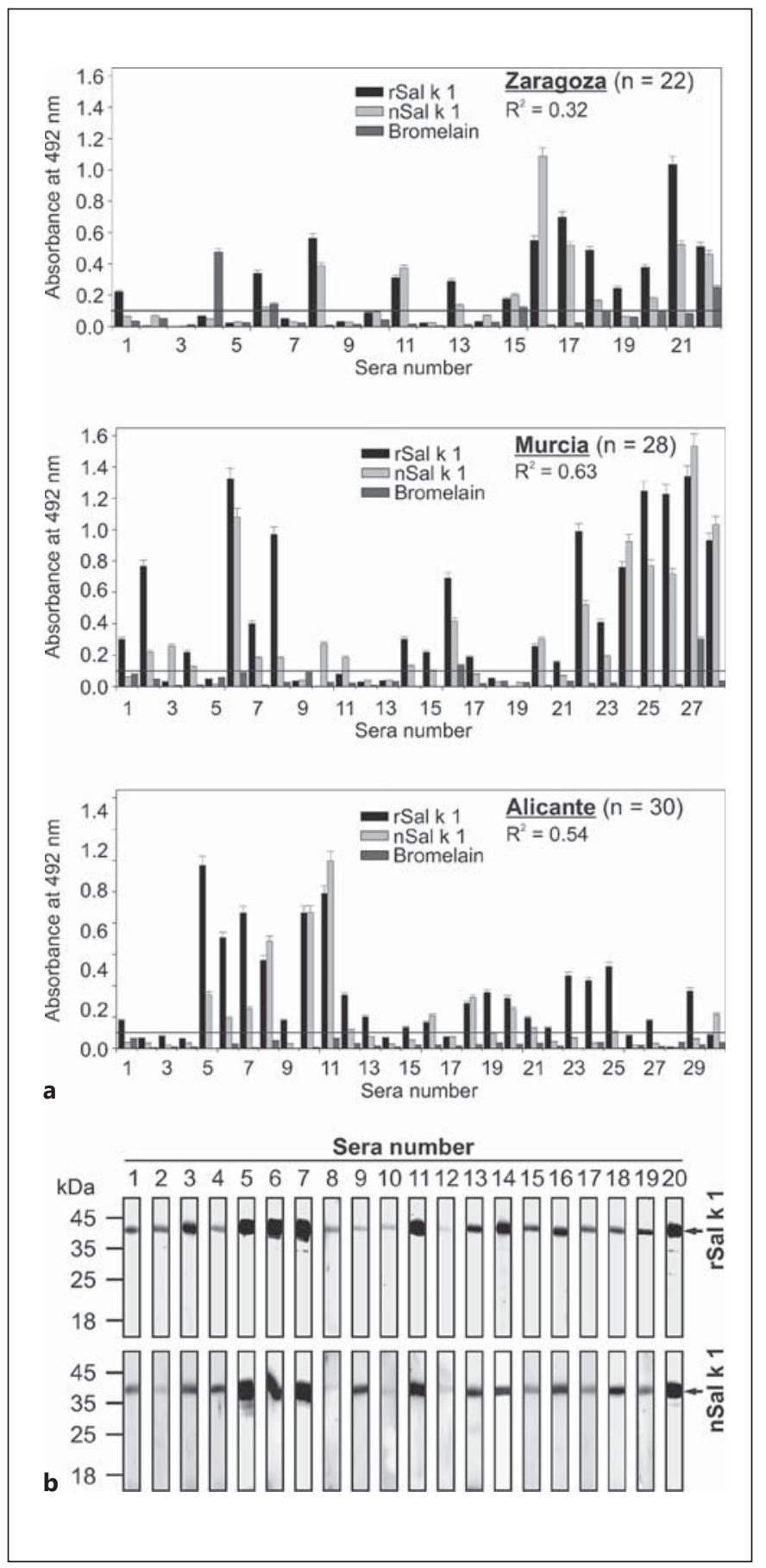

Fig. 3. Specific IgE binding of $\mathrm{rSal} \mathrm{k} 1$ and $\mathrm{nSal} \mathrm{k} 1$. a Determination of the IgE-binding ability of 80 individual sera from 3 regions of Spain to rSal k 1 (100 ng/well), nSal k 1 (100 ng/well) or bromelain (500 ng/well). Correlation coefficient $\left(\mathrm{R}^{2}\right)$ among rSal k 1 and $\mathrm{nSal} \mathrm{k} 1 \mathrm{IgE}$ levels is also shown for each population. $\mathbf{b}$ Analysis of the specific IgE-binding of 20 sera to $200 \mathrm{ng}$ of nitrocellulose-blotted rSal k 1 or nSal k 1 after SDS-PAGE under reducing conditions. Molecular mass markers are shown. 

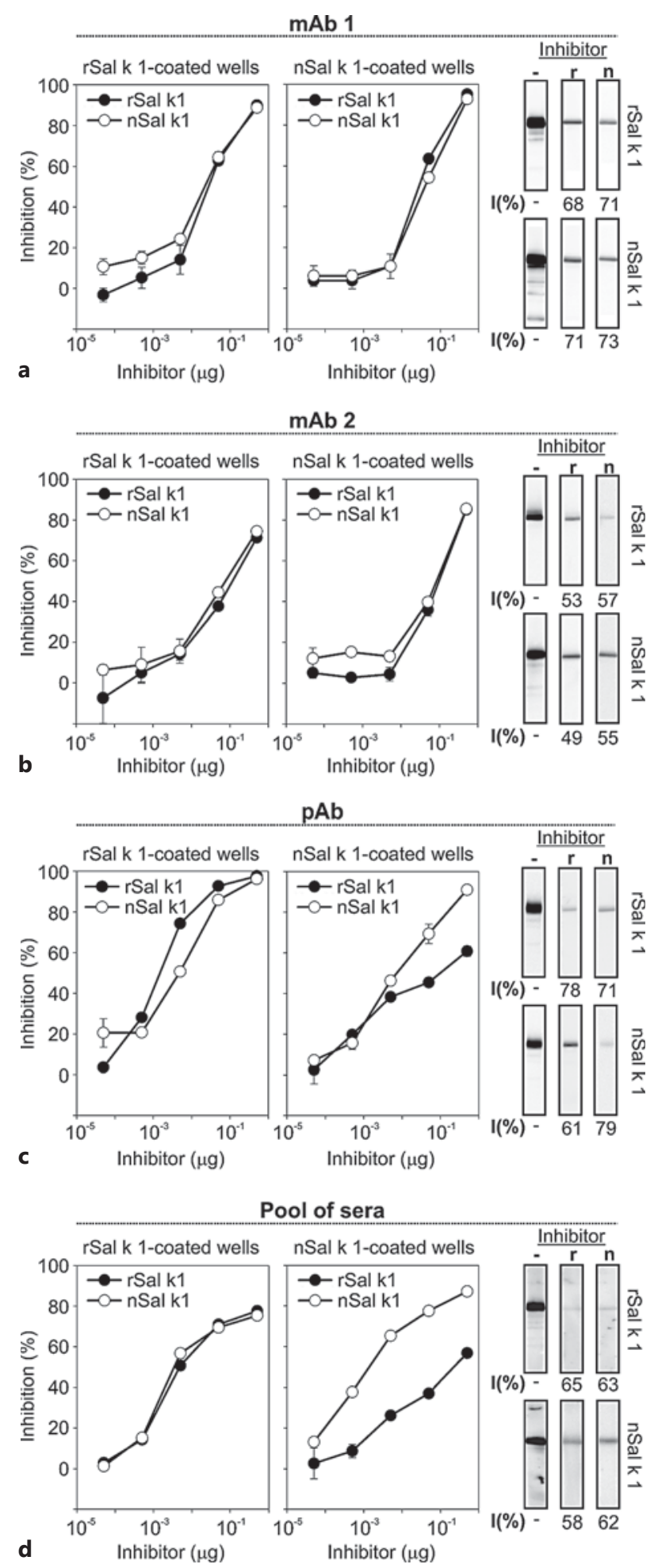
DOI: $10.1159 / 000434680$ equivalent, suggesting that the antibodies recognized the epitopes in $\mathrm{nSal} \mathrm{k} 1$ and $\mathrm{rSal} \mathrm{k} 1$ in a similar manner (fig. 2d).

We also evaluated the allergenic properties of both proteins by ELISA and WB. The prevalence of both natural and recombinant proteins was tested using sera of $S$. kalisensitized patients from 3 different regions of Spain with significantly different $S$. kali pollen counts (fig. 3). Recognition frequency was almost equivalent for the 2 proteins nSal k 1 (52\%) and rSal k 1 (56\%). Glycoprotein bromelain with a carbohydrate very similar to that of plant glycoproteins was tested to identify those sera able to recognize the carbohydrate moiety of glycoallergens. Interestingly, only $6 / 80$ patients tested possessed IgE reactivity against the glycan of bromelain (fig. 3a), indicating that the global contribution of the carbohydrate moiety to the IgE reactivity of Sal k 1 was not relevant in this case. Correlation values obtained when the IgE-binding ability of $n S a l k 1$ and $\mathrm{rSal} \mathrm{k} 1$ was compared were quite low for all patients $\left(r^{2}=0.45\right)$, especially for the population of Zaragoza. Surprisingly, the regression analysis of the data seemed to indicate a slightly better IgE recognition of rSal k 1 by the sensitized patients than for $n S a l k 1$ in all 3 populations of sensitized patients studied (data not shown), which might have been due to a subtle partial denaturation observed by $\mathrm{CD}$ of $\mathrm{nSal} \mathrm{k} 1$ during the purification procedure.

Finally, we analyzed the IgE-binding ability of both proteins by WB under denaturing conditions, to determine the role of the conformational epitopes in the $\operatorname{IgE}$ reactivity of the sera. We used a random set of 20 of the previously identified ELISA-positive sera (fig. $3 \mathrm{~b}$ ). The correlation obtained $\left(\mathrm{r}^{2}=0.94\right)$ indicated that the $\operatorname{IgE}$ binding for the 2 proteins under denaturizing conditions was almost equivalent.

Collectively, these data indicate that $\mathrm{rSal} \mathrm{k} 1$ is able to span the antigenic and allergenic properties of Sal $\mathrm{k} 1$ isoforms found in pollen.

Fig. 4. Immunological characterization and validation of $\mathrm{rSal} \mathrm{k} 1$ in comparison with $\mathrm{nSal} \mathrm{k} 1$. a, b mAb 1 and $\mathrm{mAb} 2$. c A polyclonal antiserum. d An equivolumetric pool of 8 randomly selected sera were tested by ELISA and immunoblotting to determine the IgEbinding inhibition between $\mathrm{rSal} \mathrm{k} 1$ and $\mathrm{nSal} \mathrm{k} 1$. In the ELISA experiments, $100 \mathrm{ng} /$ well of protein were coated and indicated amounts of each protein were used as inhibitor. In the immunoblotting assays under reducing conditions, $0.5 \mu \mathrm{g}$ of each protein was blotted onto nitrocellulose membranes and $5 \mu \mathrm{g}$ of inhibitor was used. Percentage of inhibition was calculated by densitometry of protein bands. I\% = Inhibition percentage; - = no inhibition; $\mathrm{n}=\mathrm{nSal} \mathrm{k} 1 ; \mathrm{r}=\mathrm{rSal} \mathrm{k} 1$. 


\section{Inhibition Assays}

We then analyzed the IgG- and IgE-equivalence of $\mathrm{nSal} \mathrm{k} 1$ and $\mathrm{rSal} \mathrm{k} 1$ by ELISA and WB inhibition experiments (fig. 4). The IgG-binding to $\mathrm{rSal} \mathrm{k} 1$ was equivalent to that of $\mathrm{nSal} \mathrm{k} 1$ when using the $2 \mathrm{mAbs}$, but the experiments performed with the polyclonal antisera indicated that $\mathrm{rSal} \mathrm{k} 1$ was not able to completely inhibit the IgGbinding to nSal k 1 (fig. $4 a-c)$.

Regarding the IgE-binding analysis by ELISA, a 30\% reduction of the IgE-binding ability of $\mathrm{rSal} k 1$ with respect to that of $\mathrm{nSal} \mathrm{k} 1$ in native conditions was observed. Furthermore, WB inhibition analyses of $\mathrm{nSal} \mathrm{k} 1$ and $\mathrm{rSal}$ $\mathrm{k} 1$, using both proteins as inhibitors, showed similar inhibition values in all cases, thus indicating that both proteins possessed a similar IgE-inhibition capacity under denaturing conditions (fig. 4d).

\section{Basophil Activation Test}

Three subjects ( 2 allergic and 1 nonatopic control) were selected to perform a basophil activation test (BAT; fig. 5). First, we tested the natural and the recombinant proteins by ELISA. A good correlation was observed for rSal $k 1$ and nSal $k 1$ (fig. 5a). Then, we observed that rSal $\mathrm{k} 1$ and $\mathrm{nSal} \mathrm{k} 1$ performed similarly in the BAT, with only 1 patient showing up clearly positive in this analysis (fig. 5b). At $20 \mu \mathrm{g} / \mathrm{ml}$ of rSal k 1 or nSal k 1, we observed similar results for IgE-positive patients with patient No. 1 showing a BAT-positive test with nSal k 1 . At $5 \mu \mathrm{g} / \mathrm{ml}$, patient No. 2 showed a much higher activation of basophils with the recombinant molecule. In contrast, the nonatopic control was a nonresponder at all concentrations and allergen tested (fig. 5b).

\section{IgE Cross-Reactivity}

We tested a panel of pollen and plant-derived food extracts with anti-Sal $\mathrm{k} 1$ polyclonal antiserum to identify those extracts able to potentially cross-react with $\mathrm{rSal} \mathrm{k} 1$ (fig. 6a). We then surveyed the extracts described as containing allergenic PME by means of ELISA inhibition experiments to $\mathrm{rSal} \mathrm{k} 1$, using a randomly selected pool of 8 sera from S. kali-sensitized patients (fig. 6b).

Regarding pollen-protein extracts and regardless of the complete inhibition observed with $S$. kali pollen-protein extract, Platanus acerifolia (plane tree) pollen-protein extract showed the highest IgE-inhibition capacity, reaching $25 \%$ inhibition using $200 \mu \mathrm{g}$ of pollen-protein extract. Other IgG-positive PME pollen-protein extracts, namely Ligustrum vulgare (wild privet) and Syringa vulgaris (common lilac) were also able to inhibit the IgEbinding to Sal k 1, reaching 24 and 20\% inhibition, re-

Recombinant Production of Sal k 1, a

Sensitization Marker of S. kali

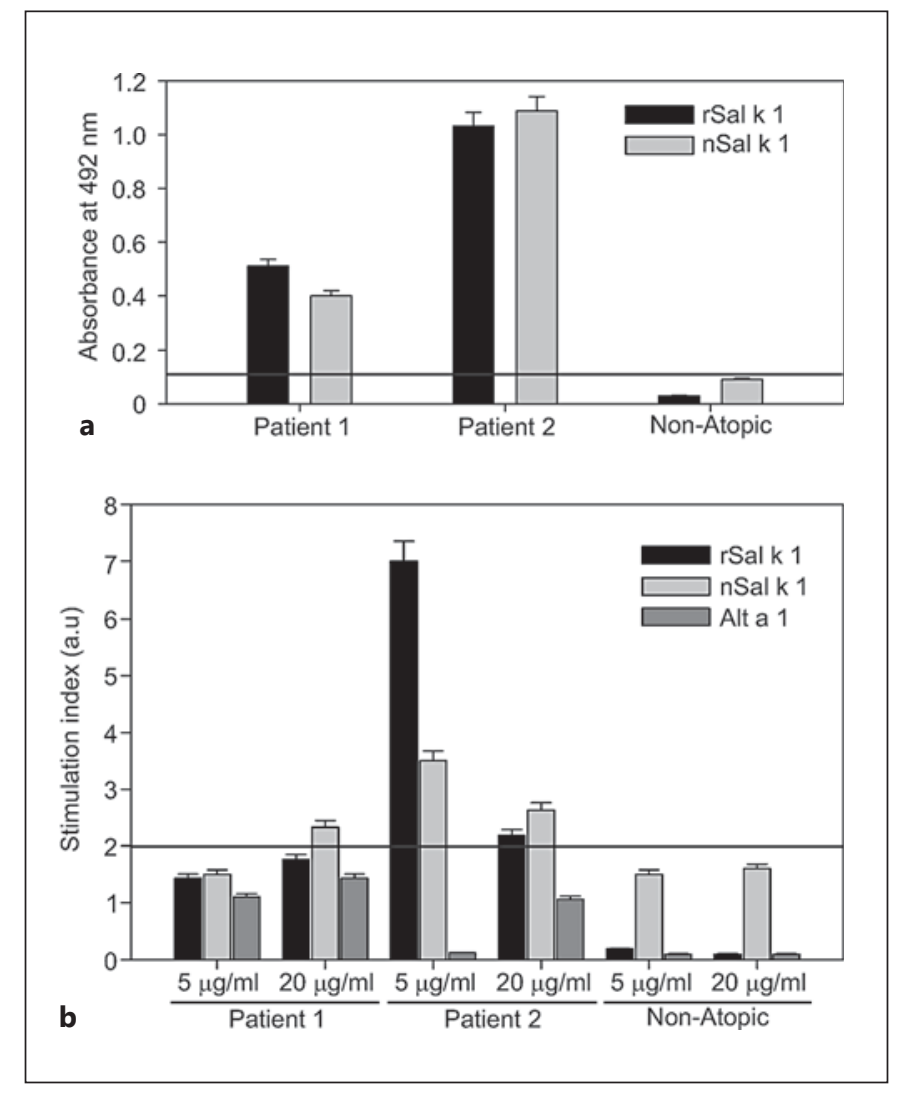

Fig. 5. Sal k 1-specific IgE values and basophil activation assays. a IgE levels (quantified by ELISA) of the $2 \mathrm{~S}$. kali pollen-sensitized patients and the nonatopic control. $\mathbf{b}$ The stimulation index of the BAT of patients allergic to $S$. kali pollen and the nonatopic control are shown.

spectively. A scarce inhibition was observed with Olea europaea (olive) or with the Amaranthaceae counterpart, C. album (Lamb's quarter).

Regarding PME plant-derived food extracts, nuts from Prunus dulcis (almond), Arachis hypogaea (peanut), Pistacia vera (pistachio) and fruits from Solanum esculentum (tomato), Solanum tuberosum (potato) and Pyrus communis (pear) were also shown to cross-react better with Sal k 1, with inhibition percentages of 40, 38, 30, 23, 22 and $18 \%$, respectively.

\section{Discussion}

The role of Amaranthaceae pollens as an important source of allergy has special relevance in countries with a desert climate, high temperatures and dry soil [22], and also extensively in areas of the south of Europe which 


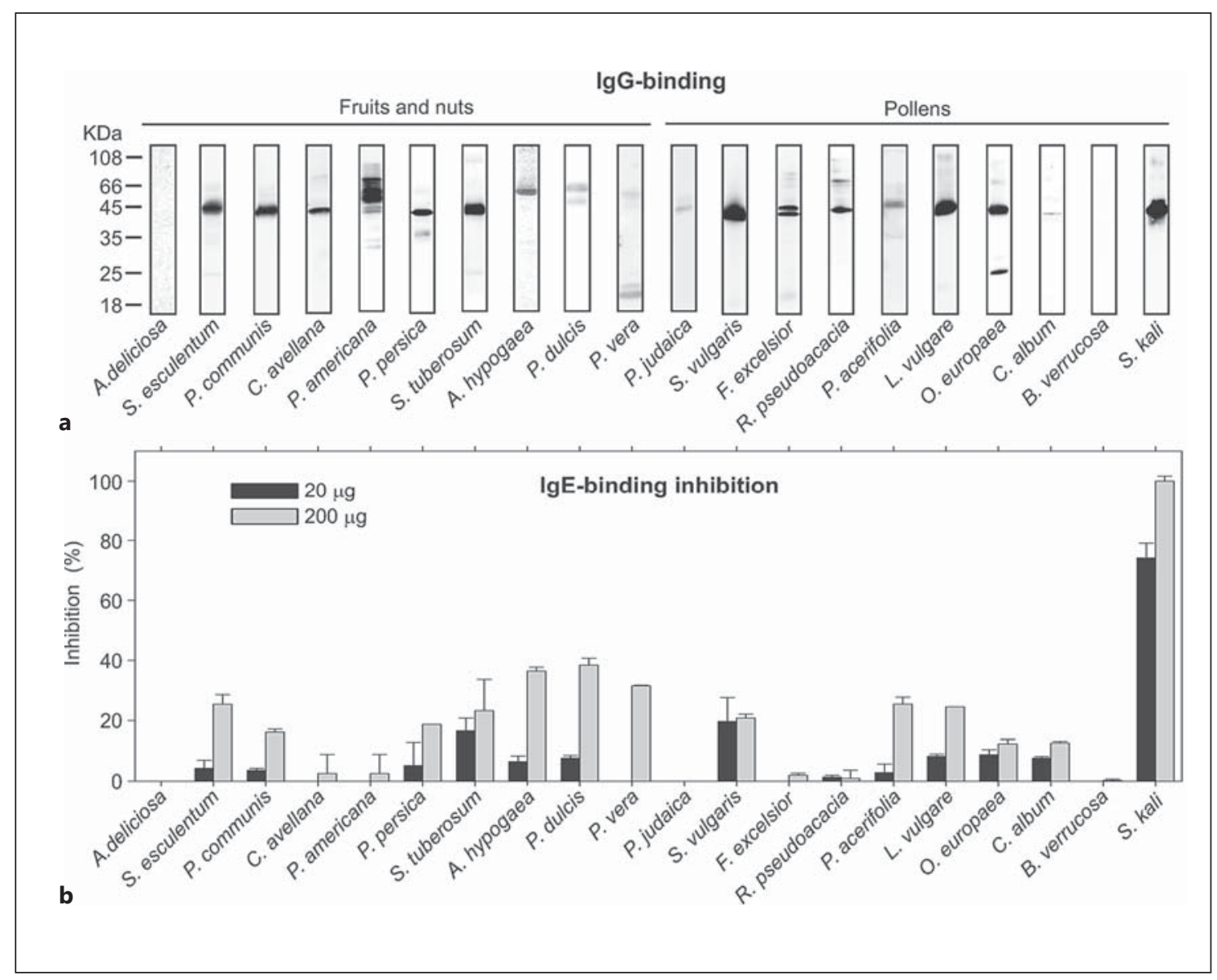

Fig. 6. Sal k 1 cross-reacts with PMEs from pollen and plant-derived foods. a Detection of PMEs from pollen and plant-derived food sources by immunoblotting using the pAb raised against Sal $\mathrm{k} 1.20 \mu \mathrm{g}$ of pollen extracts from Parietaria judaica (spreading pellitory), S. vulgaris (common lilac), Fraxinus excelsior (ash), Robinia pseudoacacia (black locust), P. acerifolia (plane tree), L. vulgare (wild privet), O. europaea (olive), C. album (lamb's quarter), Betula verrucosa (birch) and S. kali (Russian thistle), and plant-derived food extracts from Actinidia deliciosa (kiwi), S. esculentum (tomato), P. communis (pear), Corylus avellana (common hazel- nut), Persea americana (avocado), Prunus persica (peach), S. tuberosum (potato), A. hypogaea (peanut), $P$. dulcis (almond) and $P$. vera (pistachio) were blotted onto nitrocellulose membranes and immunostained with the pAb obtained against nSal $\mathrm{k} 1$. Molecular mass markers are shown. S. kali (Russian thistle) pollen extract was used as a positive control. b The same pollen and plant-derived food extracts were tested by ELISA inhibition experiments using a pool of sera from allergic patients to $S$. kali against $0.1 \mu \mathrm{g} /$ well of rSal k 1 . As a control, we used $200 \mu \mathrm{g}$ of $S$. kali pollen-protein extract. have suffered from an increased desertification process in recent years $[4,5]$. Although $S$. kali is considered the main allergenic pollen from Salsola sp., and their pollen allergens have been studied extensively in the last years [6], other Salsola sp. like S. oppositifolia and S. vermiculata have recently shown an important allergenic capacity [33].

To date, 5 allergens from $S$. kali have been reported: the protein kinase homolog Sal k 2 (accession No. Q8L5K9), methionine synthase Sal k 3 [14], the profilin Sal k $4[15,16]$, the Ole e 1-like protein Sal k 5 and the major allergen and S. kali-specific marker Sal k 1, the subject of this study [11].

Sal k 1 is a very polymorphic molecule with multiple protein spots identified on 2-dimensional electrophoresis, a pI ranging from 5.9 to 7.7 and different glycosylation patterns [11]. As this heterogeneity hampers the development of a suitable purification procedure to obtain a consistent and reproducible batch-to-batch protein preparation, a recombinant approach is especially helpful here. Thus, our main concern about the production of Sal k 1 consisted of obtaining a recombinant protein able to be 
recognized by all patients sensitized to $S$. kali. As previously reported, nonglycosylated PMEs like that of Diospyros kaki conserved their 3-dimensional folding and its enzymatic activity when comparing with other glycosylated PMEs [34]. Thus, we expressed Sal k 1-specific cDNA in bacteria because glycosylation should not be critical for the 3-dimensional folding of PMEs [34], and it has also been successfully used to express other glycosylated allergens, which maintained intact structural and immunological properties $[35,36]$.

We performed an extensive characterization of $\mathrm{rSal} \mathrm{k}$ 1 produced in E. coli in comparison to $\mathrm{nSal} \mathrm{k} 1$, to verify that the recombinant protein possessed similar structural and immunological properties to the allergen isolated from pollen. We observed differences between rSal k 1 and $\mathrm{nSal} \mathrm{k} 1$ in the secondary structure, indicating that $\mathrm{nSal} \mathrm{k} 1$ could have suffered from structural changes during its purification process. However, we determined that the most general features of PMEs, such as the percentage of $\beta$-sheet, were present in both forms. On the other hand, the antigenic behavior of $\mathrm{rSal} \mathrm{k} 1$ was almost equivalent to $\mathrm{nSal} \mathrm{k} 1$, pointing out that the structural similarity of the 2 proteins was very high. No significant differences were observed in the IgE-binding of these proteins under denaturing conditions. With ELISA, we observed that IgE-binding was similar when both proteins were tested individually, biased towards a slightly better recognition to $\mathrm{nSal} \mathrm{k} 1$ (about $30 \%$ of reduced inhibition ability of rSal $\mathrm{k} 1$ with respect to $\mathrm{nSal} \mathrm{k} 1$ ) when tested in inhibition experiments. However, the differences observed cannot be attributed to a wrong folding of the recombinant protein, since 37 individual sera gave a better recognition to rSal $\mathrm{k} 1$ and 15 to $\mathrm{nSal} \mathrm{k} 1$.

To determine if differences in the IgE-binding to rSal $\mathrm{k} 1$ and $\mathrm{nSal} \mathrm{k} 1$ could be attributed to the glycan moieties, absent in rSal k 1 , or to conformational epitopes absent in the selected isoform, we also tested bromelain, a protein containing cross-reactive carbohydrate determinant. Only $6.6 \%$ of the patients showed specific IgE directed to the glycosydic fractions found in bromelain, and only 1 patient (1.1\% of the population) showed a correlation between the IgE reactivity to the glycan moiety and a better recognition of the natural protein. We could confirm that the contribution of the glycan moiety to the whole IgEreactivity of nSal $\mathrm{k} 1$ was not relevant in the assayed population, as it has also been reported for cross-reactive carbohydrate determinants in a clinical context [37, 38]. Remarkably, as previously described for glycoallergens in general [37], the glycan moiety present in nSal $\mathrm{k} 1$ could misdiagnose IgE-reactive patients to cross-reactive car-

Recombinant Production of Sal k 1, a Sensitization Marker of S. kali bohydrate determinants. The implementation of rSal $\mathrm{k} 1$ in diagnostic protocols would circumvent these problems because of the absence of glycosylation in the recombinant allergen.

Collectively, our results seemed to indicate that differences in the allergenic recognition with some bias towards rSal $\mathrm{k} 1$ by individual ELISA and to nSal $\mathrm{k} 1$ in IgE-inhibition assays could mainly be attributed to the high number of amino acid changes inside of the conformational epitopes due to the polymorphism of the natural protein. These modifications are able to induce changes in the affinity and specificity of the IgE antibodies, when both proteins are tested individually and in ELISA IgE-inhibition assays, as we observed previously in Sal k 4 [15]. Another possibility could be that a subtle partial denaturation of $\mathrm{nSal} \mathrm{k} 1$ during the purification procedure produces a bias to $\mathrm{rSal} \mathrm{k} 1$ by individual ELISA. Finally, we further confirmed the equivalence of rSal $\mathrm{k} 1$ and $\mathrm{nSal} \mathrm{k} 1$ by BAT. rSal $\mathrm{k} 1$ was able to induce basophil activation from the blood of $S$. kali pollen-sensitized patients at a similar level to $\mathrm{nSal} \mathrm{k} 1$, correlating BAT values with the IgE levels to rSal $k 1$ and $n S a l k 1$ of this selected population of sensitized patients. Of note, these data confirmed the usefulness of rSal $\mathrm{k} 1$ for in vitro diagnosis.

We investigated the potential role of Sal k 1 in crossreactivity for 3 main reasons. First, the biochemical function of this protein family is associated with a well-conserved catalytic amino acid core across species $[11,20]$, which might be an immunogenic target for the IgE from sensitized patients. Second, the existence of allergenic PMEs in pollen, e.g. Ole e 11 in olive pollen, with a range of prevalence of $55.9-75.6 \%$ in 3 different allergic populations [20], and plant-derived foods like tomato [21,22] or kiwi (Act d 7), with a 32\% prevalence [23], could be indicative of a protein involved in cross-reactivity processes. And third, it was recently published that there is a higher prevalence of Sal $k 1$ in patients sensitized to plantderived food and pollen than in patients sensitized only to pollen [19], suggesting a potential implication of this allergen in pollen to plant-derived food cross-reactivity. Here, we have confirmed the role of Sal $\mathrm{k} 1$ in cross-reactivity, as deduced from the inhibition experiments performed with a panel of plant-derived food and pollen extracts. Although the extracts tested might contain different isoforms of PMEs, diverse amounts of PME or different amounts of structurally related PMEs to Sal k 1, we observed significant inhibition ranging from 9 to $24 \%$ with allergenic pollens and from 18 to $40 \%$ with plantderived food extracts. 
In summary, this work shows that rSal k 1 (1) was almost equivalent to $\mathrm{nSal} \mathrm{k} 1$ regarding its physicochemical properties, (2) spanned most of the allergenic properties of the natural isoforms present in S. kali pollen and (3) was almost equivalent to $\mathrm{nSal} \mathrm{k} 1$ at an allergenic level, as demonstrated by immunological approaches and by histamine release. Accordingly, the data we present here provide evidence that $\mathrm{rSal} \mathrm{k} 1$ might replace $\mathrm{nSal} \mathrm{k} 1$ in the diagnostic protocols currently used in clinics and could be considered for future use in immunotherapy protocols in S. kali pollen-sensitized patients.

\section{Acknowledgements}

We thank Sara Abián for the excellent technical support. This work was supported by grants SAF2011-26716 and SAF201453209-R from the Ministerio de Economía y Competitividad and RIRAAF Network RD12/0013/0015 from the ISCIII. R.B. is a fellow of the Ramón y Cajal program of the Ministerio de Economía y Competitividad, Spain.

\section{Disclosure Statement}

P.B. and R.I.M. belong to the Research Department of ALKAbelló S.A. The rest of the authors declare no conflict of interest.

\section{References}

1 Chivato T, Valovirta E, Dahl R, de Monchy J, Bloch Thomsen A, Palkonen S, Jacobsen L: Allergy, living and learning: Diagnosis and treatment of allergic respiratory diseases in Europe. J Invest Allergol Clin Immunol 2012; 22:168-179.

$>2$ Reid CE, Gamble JL: Aeroallergens, allergic disease, and climate change: impacts and adaptation. EcoHealth 2009;6:458-470.

-3 Gadermaier G, Dedic A, Obermeyer G, Frank S, Himly M, Ferreira F: Biology of weed pollen allergens. Curr Allergy Asthma Rep 2004;4: 391-400.

-4 Barber D, de la Torre F, Feo F, Florido F, Guardia P, Moreno C, Quiralte J, Lombardero M, Villalba M, Salcedo G, Rodríguez R: Understanding patient sensitization profiles in complex pollen areas: a molecular epidemiological study. Allergy 2008;63:1550-1558.

5 Colás C, Lezaun A: Russian thistle pollinosis: form allergen characterization to specific immunotherapy treatment. Front Biosci 2009; 14:4652-4657.

6 Villalba M, Barderas R, Mas S, Colás C, Batanero E, Rodriguez R: Amaranthaceae pollens: review of an emerging allergy in the Mediterranean area. J Invest Allergol Clin Immunol 2014;24:371-381.

7 Colás C, Monzon S, Venturini M, Lezaun A: Double-blind, placebo-controlled study with a modified therapeutic vaccine of Salsola kali (Russian thistle) administered through use of a cluster schedule. J Allergy Clin Immunol 2006;117:810-816.

$>8$ Barber D, de la Torre F, Feo F, Florido F, Guardia P, Moreno C, Quiralte J, Lombardero M, Villalba M, Salcedo G, Rodriguez R: Understanding patient sensitization profiles in complex pollen areas: a molecular epidemiological study. Allergy 2008;63:1550-1558.

$>9$ Flores E, Cervera L, Sanz ML, Diaz-Perales A, Fernandez J: Plant food allergy in patients with pollinosis from the Mediterranean area. Int Arch Allergy Immunol 2012;159:346-354.
10 Lombardero M, Duffort O, Sellés JG, Hernández J, Carreira J: Cross-reactivity among Chenopodiaceae and Amaranthaceae. Ann Allergy $1985 ; 54: 430-436$.

11 Barderas R, García-Selles J, Salamanca G, Colás C, Barber D, Rodríguez R, Villalba M: A pectin methylesterase as an allergenic marker for the sensitization to Russian thistle (Salsola kali) pollen. Clin Exp Allergy 2007;37:11111119.

12 Barderas R, Villalba M, Lombardero M, Rodríguez R: Identification and characterization of Che a 1 allergen from Chenopodium album pollen. Int Arch Allergy Immunol 2002;127: 47-54.

-13 Barderas R, Villalba M, Pascual CY, Batanero E, Rodríguez R: Profilin (Che a 2) and polcalcin (Che a 3) are relevant allergens of Chenopodium album pollen: isolation, amino acid sequences, and immunologic properties. J Allergy Clin Immunol 2004;113:1192-1198.

-14 Assarehzadegan MA, Sankian M, Jabbari F, Tehrani M, Falak R, Varasteh A: Identification of methionine synthase (Sal k 3), as a novel allergen of Salsola kali pollen. Mol Biol Rep 2011;38:65-73.

-15 Mas S, Barderas R, Colás C, Quiralte J, Rodríguez R, Villalba M: The natural profilin from Russian thistle (Salsola kali) contains a low IgE-binding ability isoform - molecular and immunological characterization. FEBS J 2012;279:4338-4349.

-16 Assarehzadegan MA, Amini A, Sankian M, Tehrani M, Jabbari F, Varasteh A: Sal k 4, a new allergen of Salsola kali, is profilin: a predictive value of conserved conformational regions in cross-reactivity with other plant-derived profilins. Biosci Biotechnol Biochem 2010;74:1441-1446.

17 Castro L, Mas S, Barderas R, Colás C, GarcíaSellés J, Barber D, Rodríguez J, Villalba M: Sal $\mathrm{k} 5$, a member of the widespread Ole e 1-like protein family, is a new allergen of Russian thistle (Salsola kali) pollen. Int Arch Allergy Immunol 2014;163:142-153.
18 Villalba M, Barderas R, Mas S, Colás C, Batanero E, Rodríguez R: Amaranthaceae pollens: review of an emerging allergy in the Mediterranean area. J Invest Allergol Clin Immunol 2014;24:288-297.

19 Cuesta-Herranz J, Barber D, Blanco C, Cistero-Bahima A, Crespo JF, Fernández-Rivas M, Fernández-Sanchez J, Florido JF, Ibáñez MD, Rodríguez R, Salcedo G, García BE, Lombardero M, Quiralte J, Rodríguez J, Sánchez-Monge R, Vereda A, Villalba M, Alonso Díaz de Durana MD, Basagana M, Carrillo T, Fernández-Nieto M, Tabar AI: Differences among pollen-allergic patients with and without plant food allergy. Int Arch Allergy Immunol 2010;153:182-192.

20 Salamanca G, Rodríguez R, Quiralte J, Moreno C, Pascual CY, Barber D, Villalba M: Pectin methylesterases of pollen tissue, a major allergen in olive tree. FEBS J 2010;277:27292739.

21 Kondo Y, Urisu A, Tokuda R: Identification and characterization of the allergens in the tomato fruit by immunoblotting. Int Arch Allergy Immunol 2001;126:294-299.

-22 Welter S, Lehmann K, Dolle S, Schwarz D, Weckwerth W, Scheler C, Worm M, Franken $\mathrm{P}$ : Identification of putative new tomato allergens and differential interaction with IgEs of tomato allergic subjects. Clin Exp Allergy 2013;43:1419-1427.

-23 Ciardiello MA, D’Avino R, Amoresano A, Tuppo L, Carpentieri A, Carratore V, Tamburrini M, Giovane A, Pucci P, Camardella L: The peculiar structural features of kiwi fruit pectin methylesterase: amino acid sequence, oligosaccharides structure, and modeling of the interaction with its natural proteinaceous inhibitor. Proteins 2008;71:195-206.

24 Makatsori M, Pfaar O, Lleonart R, Calderón MA: Recombinant allergen immunotherapy: clinical evidence of efficacy - a review. Curr Allergy Asthma Rep 2013;13:371-380. 
25 Valenta R, Linhart B, Swoboda I, Niederberger V: Recombinant allergens for allergenspecific immunotherapy: 10 years anniversary of immunotherapy with recombinant allergens. Allergy 2011;66:775-783.

26 Palomares O, Cuesta-Herranz J, Vereda A, Sirvent S, Villalba M, Rodríguez R: Isolation and identification of an 11s globulin as a new major allergen in mustard seeds. Ann Allergy Asthma Immunol 2005;94:586-592.

27 Loughran ST, Walls D: Purification of polyhistidine-tagged proteins. Methods Mol Biol 2011;681:311-335.

28 Garnier J, Gibrat JF, Robson B: GOR method for predicting protein secondary structure from amino acid sequence. Methods Enzymol 1996;266:540-553.

-29 Wilkins MR, Gasteiger E, Bairoch A, Sanchez JC, Williams KL, Appel RD, Hochstrasser DF: Protein identification and analysis tools in the ExPASy server. Methods Mol Biol 1999;112: 531-552.

30 Marazuela EG, Hajek R, Villalba M, Barber D, Breiteneder H, Rodríguez R, Batanero E: A non-allergenic Ole e 1-like protein from birch pollen as a tool to design hypoallergenic vac- cine candidates. Mol Immunol 2012;50:8390.

31 van Ree R, Cabanes-Macheteau M, Akkerdaas J, Milazzo JP, Loutelier-Bourhis C, Rayon C, Villalba M, Koppelman S, Aalberse R, Rodríguez R, Faye L, Lerouge P: Beta(1,2)xylose and alpha(1,3)-fucose residues have a strong contribution in $\mathrm{IgE}$ binding to plant glycoallergens. J Biol Chem 2000;275:1145111458.

32 Díaz-Perales A, Sanz ML, García-Casado G, Sánchez-Monge R, García-Sellés FJ, Lombardero M, Polo F, Gamboa PM, Barber D, Salcedo G: Recombinant Pru $\mathrm{p} 3$ and natural Pru p 3, a major peach allergen, show equivalent immunologic reactivity: a new tool for the diagnosis of fruit allergy. J Allergy Clin Immunol 2003;111:628-633.

33 Ferrer A, Larramendi CH, Huertas AJ, Pagan JA, Andreu C, Garcia-Abujeta JL, Lopez-Matas MA, Carnes J: Allergenic differences among pollens of three Salsola species. Int Arch Allergy Imm 2010;151:199-206.

34 Ciardiello MA, Tamburrini M, Tuppo L, Carratore V, Giovane A, Mattei B, Camardella L: Pectin methylesterase from kiwi and kaki fruits: purification, characterization, and role of $\mathrm{pH}$ in the enzyme regulation and interaction with the kiwi proteinaceous inhibitor. J Agric Food Chem 2004;52:7700-7703.

35 Bordas-Le Floch V, Bussieres L, Airouche S, Lautrette A, Bouley J, Berjont N, Horiot S, Huet A, Jain K, Lemoine P, Chabre H, Batard T, Mascarell L, Baron-Bodo V, Tourdot S, Nony E, Moingeon P: Expression and characterization of natural-like recombinant Der $\mathrm{p}$ 2 for sublingual immunotherapy. Int Arch Allergy Immunol 2012;158:157-167.

36 Mittermann I, Zidarn M, Silar M, MarkovicHousley Z, Aberer W, Korosec P, Kosnik M, Valenta R: Recombinant allergen-based IgE testing to distinguish bee and wasp allergy. J Allergy Clin Immunol 2010;125:1300-1307.

37 Altmann F: The role of protein glycosylation in allergy. Int Arch Allergy Immunol 2007; 142:99-115.

38 Kaulfurst-Soboll H, Mertens M, Brehler R, von Schaewen A: Reduction of cross-reactive carbohydrate determinants in plant foodstuff: elucidation of clinical relevance and implications for allergy diagnosis. PLoS One 2011; 6:e17800. 